tell, and his book may be regarded as a guide to what the observant country resident ought to see and notice, rather than as an exponent of fresh facts. In places, indeed, he forsakes his usual style for what we suppose must be called "word-painting," but we can scarcely congratulate him on the result of the change. Neither, we think, is he altogether happy in his theory that bird-song is largely due to rivalry and jealousy; although his eagerness to trace out the reason of every phenomenon in natural life is a trait deserving of the highest commendation.

The reader who follows in Mr. Robinson's foot-
A short time previously, Huxley, assisted by $\mathrm{T}$. J. Parker, had begun to organise his pioneer practical classes in biology at South Kensington, and Howes's first scientific work consisted in making a series of enlarged coloured drawings illustrating the anatomy of various animals, and thus further developing his powers as a draughtsman. These drawings now form the well known series hanging on the walls of the laboratory at the Royal College of Science, copies of which were subsequently made by Howes for use in various universities and colleges in this country and abroad. Although he had no previous scientific training, he rapidly became an expert anatomist, and many of his exquisite dissections are still to be seen on the shelves of the laboratory.

All this time, Howes was taking every advantage of his opportunities for studying under our greatest biological teacher in a school of high tradition, where students are able to devote themselves to one subject at a time, and are fortunate in being unhampered by syllabuses. $\mathrm{He}$ was soon appointed assistant demonstrator, and on Parker's election to the chair of biology in the University of Otago, Howes succeeded him as chief demonstrator, so that his originality, zeal, and enthusiasm had full scope for development. The wide knowledge he gradually obtained of his subject, his valuable contributions to zoological literature, and

Fig. r.-Young Peewit hiding. From "The Country Day by Day." more especially his power

steps and takes him as guide will not have much to learn about the animals and plants of his native district after a year's diligent apprenticeship.

R. L.

\section{PROF. G. B. HOWES, F.R.S.}

CEORGE BOND HOWES, whose state of health for the past two years had been the cause of grave anxiety, passed away on February 4 . Born in London on September 7,1853 , his active and useful life was cut short at the age of fifty-one.

Howes was of Huguenot extraction; his father, the late T. J. Howes, married the daughter of the late Captain G. H. Bond-a member of a talented family. While attending a private school he spent his spare time in making microscopical slides, and a prize of one of J. G. Wood's books helped to arouse further his interest in natural history. His parents at first intended that he should prepare for entering the Church, but this plan was given up, and on leaving school he was for a short time in business, which proved very distasteful to him. Having worked out the anatomy of the house-fly, made careful drawings of his preparations, and given a lecture on the subject, his talent was recognised by a friend of the family-a clergyman-who introduced him to $\mathrm{Mr}$. Walter White, then secretary to the Royal Society. Through Mr. White's instrumentality an introduction was obtained to Prof. Huxley, and this resulted in an appointment under the Science and Art Department.

NO. I 844 , vOI, 7 I] and influence as a teacher, soon made it apparent scientific world. On Huxley's partial retirement in I 885, Howes was appointed assistant professor, and in 1895 - when the chair of biology was subdivided--professor of zoology. During his career as demonstrator, he had also for two years held the post of lecturer on comparative anatomy to the St. George's Hospital Medical School.

In 1897 , Howes was elected to the fellowship of the Royal Society. He was a vice-president of the Zoological Society, honorary zoological secretary to the Linnean Society, honorary treasurer of the Anatomical Society, ex-president of the Malacological Society, president of Section D of the British Association at the Belfast meeting, corresponding member of the New York Academy of Science, and an honorary member of the New Zealand Institu+e. He also took an active interest in the work of several local natural history societies, of which he was a member. In 1902 he acted on the committee for the reorganisation of the Zoological Gardens, and in the same year received the degree of D.Sc., honoris causa, in the Victoria University, having previously -in I 898 -received that of LL.D. at St. Andrews. He had held examinerships in several universities, e.g. London, Oxford, Victoria, and New Zealand.

The veneration and affection which Howes felt for his great chief were unbounded, and apparent in all his work, to carry on which on the lines laid down by Huxley was the summit of his ambition.

His publications are too numerous to be mentioned in detail; they consist of some fifty papers and 
addresses, as well as numerous reviews and articles, all written in a characteristic style; apart from the two editions of his well known "Atlas," and the revised and extended editions of Huxley and Martin's "Elementary Biology" (in collaboration with Prof. D. H. Scott). He also edited the translation by Bernard of Wiedersheim's "Bau des Menschen," and had undertaken to prepare a new edition of Huxley's " Anatomy of Vertebrated Animals," which he had mapped out in his mind, but never actually began. His original work deals mainly with vertebrate comparative anatomy, and all shows the same thoroughness and accurate knowledge.

Considerable and important as his direct contributions to science have been, they only represent a part of his life's work in this direction, for he considered it his duty to devote much time to the business of scientific societies and in helping any serious workers who applied to him; he spared no trouble in assisting others.

Never a robust man, Howes's power of work was extraordinary. He never seemed to be in a hurry, and did not give one the impression that he spent an excessive amount of time in reading the current literature of his subject, although his knowledge and memory in this direction were quite unique. His mind was of a remarkable type, and was, one may say, almost overburdened with details, though he never lost sight of the main issue, and was always clear and stimulating. He absorbed everything which had the remotest bearing on his science, and would talk by the hour on almost every branch of zoology; one had only to ask him some question and he would either have the point at issue at his finger-ends, or would at once give references to the most recent papers on the subject. When giving a lecture or an address, he would put so much into an hour's discourse as to make his hearers marvel at his memory and grasp of the subject. His presidential address to the zoological section of the British Association in 1902 contains no less than 186 references to original authorities, and its preparation must have cost him an enormous amount of labour at a time when he was already over-fatigued.

Howes was a man of high moral standard and ingenuous nature, generous and unselfish in all he did, and his death is mourned by a wide circle of scientific friends, who will long cherish the memory of his friendship and hospitality. He carried out his own belief that " higher ambition than that of adding to the sum of knowledge no man can have; wealth, influence, position, all fade before it; but we must die for it if our work is to live after us."

\section{W. N. P}

\section{NOTES.}

THE following fifteen candidates have been selected by the council of the Royal Society to be recommended for elfction into the society:-Mr. J. G. Adami, Mr. W. A. Bone, Mr. J. E. Campbell, Mr. W. H. Dines, Capt. A. Mostyn Field, R.N., Mr. M. O. Forster, Mr. E. S. Goodrich, Mr. F. G. Hopkins, Mr. G. W. Lamplugh, Mr. E. W. MacBride, Prof. F. W. Oliver, Lieut.-Col. D. Prain, I.M.S., Mr. G. F. C. Searle, Hon. R. J. Strutt, and Mr. E. T. Whittaker.

THE piercing of the Simplon Tunnel was completed at 7.20 a.m. on February 24. At the time of piercing, the north gallery was inaccessible on account of the accumulation of water. The south gallery is on a lower level than the north, and the final connection was made by the explosion of charges placed in holes driven into the roof of the south gallery, which left a large hole on a level with the floor of No. 1844 , VOL. 7 I] the north gallery. No sooner was the piercing effected than the accumulated water flowed rapidly away down the southern side, and was discharged into Italy without doing damage. It is unnecessary again to direct attention to the particulars of this triumph of engineering skill, for a detailed account of the difficulties with which the engineers have had to contend, and the expedients utilised to surmount these obstacles, will be found in an article by $\mathrm{Mr}$. Francis Fox in Nature for October 27 , I904 (p. 628, vol. 1xx.). The work that now remains to be done is to put in place the masonry arching, to cover over the water channel beneath the floor of the tunnel, and to lay the permanent way. It is expected that within three months trains will be running, and the railway will prove a vital link in the line of communication between the Italian cities and mid-Europe.

ON Friday, March 17, Senor Manuel Garcia, the inventor of the laryngoscope, will complete his hundredth year, and the anniversary will be celebrated by a meeting of laryngologists at the rooms of the Royal Medico-Chirurgical Society, Hanover Square. We learn from the British Medical Journal that the Spanish Ambassador will attend to congratulate the illustrious centenarian in the name of the Government of his native country, and among the addresses will be one from the Royal Society, before which Senor Garcia read his paper entitled "Physiological Observations on the Human Voice" just fifty years ago. The Berlin, Vienna, French, Dutch, Belgian, and South and West German Laryngological Societies will send special deputations. Most of the addresses will be taken as read, and the proceedings will conclude with the presentation of a portrait of Senor Garcia, painted by Mr. John Sargent, R.A., together with an album containing the names of all the subscribers. In the evening a banquet will take place at the Hotel Cecil, at which it is hoped that Senor Garcia himself will be present.

THE death is announced, on February 6, of Father Timoteo Bertelli, Father Bertelli was born in Bologna in 1826 , and was the son of the professor of astronomy at the University of Bologna. At eighteen he joined the Order of the Barnabites, and taught physics in various colleges of the Order. In $187 x$ he joined the College de la Querce in Florence, with which institution he appears to have been associated continuously until the time of his death, except for the three years $1895-7$, when he was called to Rome by Leo XIII. to succeed Father Denza at the Vatican Observatory. But his state of health did not permit him permanently to accept this position, and in 1897 he returned to Florence. Father Bertelli first devoted himself to meteorology, and later was attracted by the study of seismic phenomena, inventing the tromometer to assist in his observations. He gave much attention to researches into the history of the sciences and especially to that of the mariner's compass. The results of his life's work are contained in some sixty memoirs, the first of which is dated 1859 .

DR. A. S. PACKARD, professor of zoology and geology at Brown University, died on February $\mathrm{I}_{4}$, at the age of sixty-six years. The death occurred, on February 22, of Dr. Ernst F. Dürre, formerly professor of metallurgy at Aix-la-Chapelle, and author of several important treatises on the metallurgy of iron and steel. Dr. Guido Hauck, professor of mathematics at the Berlin Technical College, died on January 14. The deaths are also announced of J. C. V. Hoffmann, founder and editor of the Zeitschrift für mathematischen und naturwissenschaftlichen Unterricht, Dr. T. H. Behrens, professor of microchemistry at Delfdt, Prof. Ludwig von Tetmeyer, principal of the Vienna Technical College, and Prof. Ditscheiner, of Vienna. 